\section{Interdependence and asymmetries: Latin American ADRs and developed markets}

\author{
Ana Carolina Costa Correa ${ }^{\dagger}$ \\ Universidade de São Paulo (FEA-RP/USP), Ribeirão Preto, SP, Braz̧il \\ Tabajara Pimenta Júnior $\Omega$ \\ Universidade de São Paulo (FEA-RP/USP), Ribeirão Preto, SP, Brazil \\ Luiz Eduardo Gaio $¥$ \\ Universidade Estadual de Campinas (FCA/UNICAMP), Limeira, SP, Brazil
}

\section{ABSTRACT}

The ADRs market presented great growing importance in the last decades, specially for companies based on developing countries, such as those of Latin America. In this context, this research sought to detect and measure the interdependence phenomenon, comprising the returns and volatility spillovers and their asymmetries between the levels 2 and 3 ADRs of the main capital markets of Latin America (Brazil, Argentina, Chile and Mexico) and the developed ones (the United States, Japan, the United Kingdom and France), regarding the last financial crisis scope. This phenomenon was investigated considering both the daily returns of their market stock indices, such as those of the ADRs indices created in this study, from June 2008 to May, 2015, via VAR-MGARCH multivaried skewness models, with diagonal VECH representation. The main conclusion was that the ADR indices presented greater interdependence with the developed countries, compared to the analyzed Latin American equity markets.

Keywords: Volatility, interdependence, asymmetries, spillovers, ADRs.

\section{INTRODUCTION}

The growing financial globalization and market integration, the result of the greatest financial liberalization of the countries, the high capital mobility and the large numbers of international economic flows, resulted in closer and closer relationships between the financial markets, whether they are developed or developing ones. This phenomenon, added to the recent financial crises, provoked greater interest on the events of volatility transmission and information flow between the markets.

According to Hwang (2014), evaluating the co-movement of financial asset returns in the global capital market and the propagation of financial crises is important for asset allocation and risk management. Moreover, not only investors and companies, but also the government has interest in the crisis propagation studies. Their main concern regarding that is that their countries'economies would be affected by a crisis whose origin took place in another country. Among them, the 2008 international financial crisis, known as the "subprime crisis", as it was considered the biggest and most important crisis since the Great
Corresponding author:

${ }^{\dagger}$ Universidade de São Paulo (FEA-RP/USP),

Ribeirão Preto, SP, Brazil

E-mail: carolcorrea@yahoo.com

${ }^{\Omega}$ Universidade de São Paulo (FEA-RP/USP),

Ribeirão Preto, SP, Brazil

E-mail: taba.jr@usp.br

${ }^{¥}$ Universidade Estadual de Campinas (FCA/

UNICAMP), Limeira, SP, Brazil

E-mail: luiz.gaio@ymail.com

Received: 05/04/2017.

Revised: 06/27/2017.

Accepted: 08/28/2017.

Published Online: 04/01/2018

DOI: http://dx.doi.org/10.15728/bbr.2018.15.4.6 
Depression of 1929. Almost all the developed countries were affected, as well as a large number of developing economies, including those of Latin America. It started in 2007 with the crisis in the U.S. real estate, in the subprime loans, which triggered a breakdown in the capital market in early 2008, and its result spread to the real economy and around the world. Thus, the financial intermediaries played a central role in the international propagation of the crash, which took place in the U.S. capital market niche to the rest of the world, according to Kalemli-Ozcan, Papaioannou \& Peydró (2013). The result was a general systemic crisis, whose consequences are still felt today.

An interesting fact on the crisis period is that, both mature and developing economies suffer the increase of volatility in asset prices which are traded in them, as pointed by the studies of Bekaert \& Harvey (1997), Huang \& Chen (2014), Jinjarak (2014), Graham, Kiviaho \& Nikkisen (2012) and Hwang (2014). Furthermore, the existing correlation between the markets tend to rise, intensifying the interdependence phenomenon between them, specially between developing and developed ones. This phenomenon is relevant mainly for the developing markets, whose financial assets usually present three common characteristics: high average returns, high volatility and low correlation with developed markets, providing an international portfolio diversification benefit. Therefore, the study of co-movement between the developed and developing countries' markets becomes so important, mainly in those periods of turmoil, in which these benefits may be reduced. Thus, there are differences between the volatility behaviors of developing and developed countries, but these differences decrease during periods of international financial crises.

Among the developing economies, it is worth highlighting Latin American capital markets because they have become more attractive to international investors, since they present high economic growth perspectives, as pointed out by Hwang (2014). Wang \& Yao (2014) add that countries in these regions play an important role in the international capital market, despite their relatively small size. That is particularly evinced after the 2008 crisis, a time when these countries had an expressive growth, mainly the economies of Brazil, Chile and Mexico. It may be that they suffered less with the impacts caused by the international crisis in relation to the developed economies. Furthermore, as highlighted by Arora, Jain \& Das (2009), Bekaert \& Harvey (1997), Chukwuoor \& Feridun (2007), Fayyad \& Daly (2010), Mody (2004), Patel (2008) and Ramos, Vermunt \& Dias (2011), there are two characteristics which make the developing markets attractive to investors and have worldwide recognition: the high returns of their financial assets and the low existing correlation between the developing and the developed capital markets.

The financial liberalization, adopted by those countries mainly from the 1990's onwards, resulted in great capital market expansion and development and the possibility of portfolio diversification for international investors. Nevertheless, this diversification requires deep knowledge of the international capital market behaviors as well as their joint movements. Thus, over the last decades, several studies were developed, such as those by Aloui (2011), Arouri, Bellalah \& Nguyen (2010), Barba \& Ceretta (2011), Beirne et al. (2010), Kenourgios \& Dimitriou (2015), Marçal et al. (2011), Martinez \& Ramirez (2011), Matos, Siqueira \& Trompieri (2014), Pimenta Jr. (2012), Rejeb \& Arfaoui (2016), Romero-Meza et al. (2015), Santos (2015) and Valenzuela \& Rodríguez (2015), who investigated the market co-movements, which can be seen as volatility transmission between them.

There may be several interrelation types between financial markets. The most studied ones are the phenomena of integration, interdependence, financial contagion and spillovers, in which the existence of skewness is common.

The integration between international markets is a phenomenon usually caused by the economic globalization of these markets. Obadan (2006) states that the financial globalization or the integration of international financial markets refer to the growing 
BBR

15,4

unification of the markets around the world, reflected on greater and greater relationships between the developed and developing financial markets. That happens via trade, financial flows, exchange of technologies and information and the movement of people.

For the contagion and interdependence characterization, we adopted Forbes \& Rigobon's (2002) most accepted and widely used definition that contagion is characterized by a significant increase in the market bonds after the occurence of a shock in a country or group of countries. On the other hand, the interdependence was defined as the existence of a high correlation level between the financial markets, suggesting strong bonds between those two economies, whether in times of crisis or in periods of relative stability. Given the background, we considered the return and volatility spillovers between markets a type of interdependence, which may or may not characterize contagion.

An important factor is the spillover direction. Literature broadly approaches the spillovers, which take place from developed countries to the developing ones, as pointed by the results of the studies by Calvo \& Reinhart (1996), Mericet al. (2001), Bae, Karolyi \& Stulz (2003), Hwang (2014), Matos, Siqueira \& Trompieri (2014), Valenzuela \& Rodríguez (2015) and Coronado et al. (2016). Nonetheless, it is possible that they also exist from developing countries towards the developed ones, between the developing ones or even between the developed ones. Moreover, the existence of skewness in co-movements between different capital markets is very common. Usually, they indicate that a negative shock in a market causes more overwhelming reactions in other markets than a positive shock of the same magnitude. Such a fact is known as "leverage effect".

Considering that the majority of the studies approach this spillover issue only in the stock markets and the indexes of the developed countries for the developing ones, the study aims to answer the following question: How do the level 2 and 3 ADR markets of Latin American companies behave in relation to the main developed and developing capital markets of Latin America as part of an international financial crisis, regarding the phenomena of interdependence and skewness of returns and volatility?

Thus, as the overall purpose of this study, we sought to detect and measure the interdependence phenomenon, comprising the return and volatility spillovers and their asymmetries, between the main Latin American capital markets and the developed countries, during the last international financial crisis - the U.S. subprime crisis. We looked into this phenomenon considering both their market stock indices, and the American Depositary Receipts - ADRs of Latin American companies.

The ADR market had growing importance in the last decades, especially for companies headquartered in developing countries. After financial liberalizations which took place in the 80 's and 90's in these markets, there was a large increase in the number of companies of these countries which did dual-listing of their shares issuing depositary receipts, mainly in the U.S. capital market.

Several reasons why companies decide to dual list, that is, issue depositary receipts (DRs) in developed markets, such as the ADRs can be listed. The hypothesis of market segmentation is one of the main explanations, and it defends that the ADR issuance allows investors to avoid boundary barriers for the investment, for instance, regulatory restrictions, information problems, such as little informative accounting practices, or even the lack of knowledge of a security. These factors are particularly important for developing markets, especially those of Latin America, whose capital markets still present several impairments, such as lack of long-term funding sources, low liquidity, little international visibility of the securities, high interest rates, low corporate governance and disclosure standards, among others. 
Other possible explanations are: the liquidity hypothesis, the information environment and the hypothesis of corporate governance and bonding. The latter one, more adherent to the research proposal, states that when bonding to more developed markets via the ADRs issuance, the companies signal the investors greater growth perspectives, more sobriety and commitment, reducing the information skewness and agency problems.

Thus, several studies list the advantages of ADRs issuance for the companies, such as those of Fanto \& Karmel (1997), Hales \& Mollick (2014), Kiymaz, Alon \& Veit (2009), Mittoo (1992), Wang, Li \& Chen (2010) and Vázquez \& Jiménez (2016). Among them, it is worth highlighting: increase the company's exposure in global markets, raising its visibility and reputation, counting on broad coverage among the analysts and the press; business expansion; enlargement of investor base to raise more expressive capital volume without depreciating their share price in local markets; greater liquidity and volume traded of their bonds; and potential reduction of their capital cost. Moreover, the foreign companies have access to the richest and most developed market in the world. These advantages are present especially for the level 2 and 3 ADRs, that is, those that are registered at the SEC and traded in the main North American stock exchanges. These securities need to meet all the SEC requirements of disclosure and reconciliation of their financial statements for U.S. GAAP or IFRS, as well as follow the listing rules and corporate governance standards of the U.S. Stock exchanges, the same way as the U.S. domestic companies do.

Thus, in general, the companies of developing countries, specially the Latin American ones which are addressed in this study, issuing of levels 2 and 3 ADRs, have characteristics very similar to those of the companies headquartered in developed markets, compared to the others of their home country, as pointed by the studies by Kiymaz, Alon \& Veit (2009), Levine \& Schmukler (2006), Vázquez \& Jiménez (2016) and Wang, Li \& Chen (2010). For instance, in general, they present standards of corporate governance and higher disclosure, greater liquidity and visibility of their bonds, have easier access to long-term loans at lower interest rates, etc. Therefore, as highlighted by Chandar, Patro \& Yezegel (2009), it is expected that the dual-listing companies of developing markets react to shocks differently from the other companies operating in their domestic market, due to the market segmentation, as well as their peculiarities.

Thus, in this study, we checked whether there is more interdependence between the ADRs of the Latin American companies traded in U.S. stock exchanges and more advanced markets than to their origin markets in general.

\section{METHODOLOGY}

The Latin American countries comprised in this study were: Brazil, Argentina, Chile and Mexico. Besides being the only ones with a representative number of ADRs traded in stock exchanges in the analysis period, they have the most developed capital markets of the region. The other elegible Latin American countries - Colombia and Peru - presented just two and four of these bonds in the period, respectively. In the developed group, the following countries were included: the United States of America, Japan, the United Kingdom and France, representing the largest world economies and the most advanced capital markets, both in terms of product and market capitalization.

As data, we used time series of daily log returns of the main stock indices of markets of eight countries, from June/2008 to May/2015. They are: S\&P500 (USA), Nikkei 225 (Japan), FTSE 100 (the United Kingdom), CAC 40 (France), Ibovespa (Brazil), Merval (Argentina), IPSA (Chile) and IPC (Mexico). They were chosen due to their capital market 
BBR

representation of the country, both in terms of trading volumes and number and variety of shares comprised. Furthermore, four ADRs indices were created, one for each Latin American market in question, whose methodology was one of this study contribution and it is described next.

In the dates in which some markets operate, while others do not, such as different holidays in the countries, for example, the historical series were equated considering the occurence of null returns in such dates. Moreover, we excluded from the series the days in which no trading occurred in all the markets analyzed simultaneously, such as Saturdays, Sundays and common holidays, following the criterion usually applied in empirical studies, such as Barba \& Ceretta's (2011). That resulted in a total of twelve time series containing 1,819 returns each.

\subsection{MeTHOdology OF CREATION OF ADR INDiCES}

The four ADR indices were formed by the quotes of their respective level 2 and 3 depository receipts traded in the main U.S. stock exchanges (NYSE, AMEX and NASDAQ). The choice of the criteria for setting them up was carried out based on that adopted by the main renowned international market indices, so that they presented consistence over time, and could be compared and analyzed between different markets, and that they were replicable by any investor who is interested in the future.

For the calculation of the indices, the following criteria was established:

\section{A. Periodicity of the PORTfolio assembly and Weighting}

In this study, the quarterly periodicity was adopted both for the ADR potfolio assembly, and the weighting of each bond weight. Thus, regarding the months in which the assembly and weight of the portfolio assets remained fixed, the following quarters were defined: June to August; September to November; December to February; and March to May.

\section{B. ADR INCLUSION AND EXCLUSION CRITERIA IN THE PORTFOLIO ASSEMBLY}

The inclusion criteria adopted for its composition are the following:

- have been traded, at least, in $80 \%$ of the auctions of the year previous to the begining of the portfolio;

- present daily average closing price higher than one dollar in the last quarter before the beginning of the portfolio;

- be the only ADR of the company traded in the period of the portfolio assembly or the security with the highest average trading volume of the year before the beginning of the portfolio.

In the final sample, 89 ADRs of the following countries were included: Argentina (21), Brazil (33), Chile (13) and Mexico (22).

\section{RELATIVE WEIGHT OF EACH SECURITY}

The ADR indices created for the Latin American countries were pondered by the market values of the shares, which were in circulation of each company included in the portfolios, according to the majority of the main international market indices.

\section{Arbitrary SCORE OF A BASE DATE}

For the calculation of the ADR indices, it was necessary to define an arbitrary score, which would initiate the quotes. Most of the market indices adopt the following values 
10,100 or 1,000 for such objective. Since the 1,000 value is the most used one for indices having relatively recent start date, it was adopted for this study as the initial value of the indices. Thus, that was the quote value of each index on the base date set (05/30/2008), which is the first day of the data series.

\section{E. INDEX CALCULATION}

For the index calculation, when an ADR enters in a portfolio, following the inclusion criteria described, it remains in it until the end of the quarter, and its weight, calculated by the index weighting criteria, is unaltered during this whole period. In the cases in which the security was not traded in some day of the quarter of the portfolio, the quote of the day before was repeated, filling in all the missing values before the index calculation in that day.

Therefore, 28 portfolios were created for each index, and the following quarters were defined: June to August, September to November, December to February and March to May.

\subsection{Data Analysis}

For the data analysis, first we conduceted a comparison between the main characteristics of the ADR indices of the market of the eight countries approached via a descriptive analysis. We also applied the Jarque-Bera test applied aiming to check whether the time series of the daily returns of the indices in analysis followed a normal distribution. To check whether the logarithmic returns were stationary, four stationary tests, called root tests, were used. They are: Augmented Dickey-Fuller test (ADF), Phillips-Perron test (PP), Elliott-RothenbergStock test (ERS) and Kwiatkowski-Phillips-Schmidt-Shin test (KPSS). Besides those, we used the BDS test to check the linearity of time series of return indices, that is, whether they presented independent and identically distributed behavior (i.i.d.). The results indicated that all the series followed a non-normal distribution, were weakly stationary and nonlinear, that is presented time dependence.

Then, we researched the phenomenon of interdependence between the capital markets of the two groups of countries - Latin America and developed ones - and the possible asymmetries present in the return and volatility spillovers by multivaried techniques. Two multivaried asymmetric VAR-MGARCH models were estimated:

- Model I - made up of the four ADR indices of Latin America and the stock indices of the developed countries;

- Model II - made up of the eight stock market indices included in the sample.

The number of lags chosen for the VAR models was the one that minimized the statistics: AIC (Akaike Information Criterion), BIC or SC (Bayesian Information Criterion or Schwarz Criterion) and HQ (Hannan-Quinn Information Criterion). Nevertheless, since they indicated different values, we used the value indicated by the BIC test, which was a lag. The reason is that in case of non-conclusive results on the number of lags, obtained by different tests, the BIC statistics tends to offer a more parsimonious indication, as demonstrated by Lütkepohl (1985).

The White test was applied to detect the presence of conditional heteroskedasticity in the residual series of the VAR models estimated. Their results indicated there is this effect and, so, a multivaried GARCH model can be estimated from the residues of each VAR.

Thus, in the VAR-MGARCH models, the VAR was used as mean equation, while the GARCH, as variance equation. Regarding the order of autoregressive terms of the MGARCH models, the first lag was chosen both for the ARCH and for the GARCH and TARCH (asymmetric) terms. Therefore, the final model applied could be described as VAR (1)-MGARCH $(1,1,1)$, with Diagonal VECH representation, proposed by Bollerslev, Engle 
BBR

15,4

\& Wooldridge (1988) and presented next. The daily conditional correlations between the pairs of indices resulting from these models were also analyzed.

According to Felipe \& Diranzo (2006), for a vector $\boldsymbol{Y}_{t}[\mathrm{n} \times 1]$, whose matrix of conditional variance and covariance is given by $\boldsymbol{H}_{t}[\mathrm{n} \times \mathrm{n}]$, the VECH-GARCH representation has the following specification:

$$
\operatorname{vech}\left(\boldsymbol{H}_{t}\right)=\operatorname{vech}\left(\boldsymbol{A}_{\mathbf{0}}\right)+\sum_{i=1}^{q} \boldsymbol{A}_{i} \operatorname{vech}\left(\boldsymbol{\varepsilon}_{t^{-i}} \boldsymbol{\varepsilon}^{\prime}{ }_{t^{-i}}\right)+\sum_{i=1}^{p} \boldsymbol{B}_{i} \operatorname{vech}\left(\boldsymbol{H}_{t^{-i}}\right)
$$

where $\boldsymbol{H}_{\boldsymbol{t}}$ is a matrix [ $\mathrm{nx} \mathrm{n}$ ] of the conditional variances, with the elements out of the main diagonal, representing covariances; $\boldsymbol{A}_{\boldsymbol{0}}$ is a defined and positive matrix of the parameters; $\boldsymbol{A}_{\boldsymbol{i}}$ and $\boldsymbol{B}_{\boldsymbol{i}}$ are matrices $\left[\frac{n(n+1)}{2} x \frac{n(n+1)}{2}\right]$ of parameters; $\boldsymbol{\varepsilon}_{\boldsymbol{t}}$ are the error terms associated to the equations of the return averages $\boldsymbol{y}_{\boldsymbol{t}}$; vech is an operator, which, applied to a symmetric matrix, makes a rearrangement of the elements of the lower triangle in a column.

Finaly, to check the diagnosis of the estimated VAR-MGARCH models, we applied the Portmanteau Ljung-Box test. The lags up to 24 were tested, and for both models, the null hypothesis of absence of serial autocorrelation in the residues was not rejected, as expected.

\subsection{ANALYSIS OF THE MAIN CHARACTERISTICS OF THE INDICES}

Figure 1 shows a graph with the evolution of the quotes of the four Latin American ADR indices. A sharp drop is observed, in the initial period, from June/2008 on, in all the indices in a similar way, due to the climax of the subprime financial crisis. Nevertheless, in the following years, they presented a quote recovery, which was not uniform among the countries.

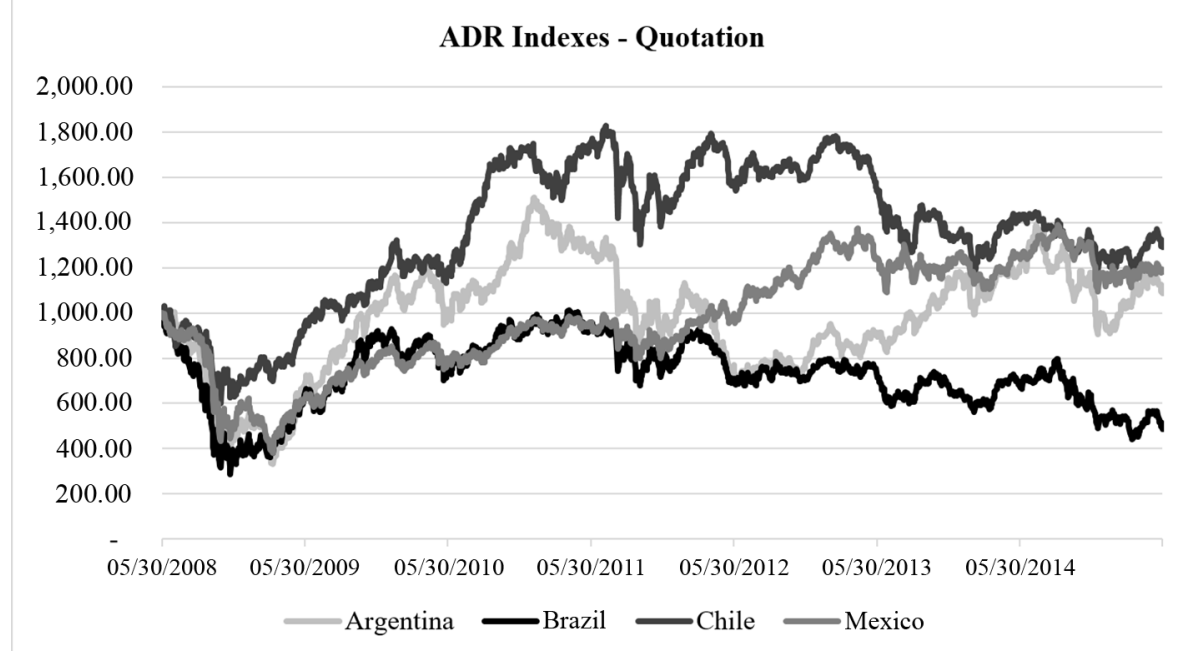

Figure 1. Quote evolution of the ADR indices.

Table 1 shows the main descriptive statistics of the daily log return series of the capital market indices under analysis. We can observe that the averages of the returns of the Latin American market indices were higher than those of the ADR indices in all the countries. Nonetheless, the ADR indices presented greater volatility, by the greater standard deviation mean. Another fact is that the Latin American stock indices showed greater return and risk in relation to the developed ones. On the other hand, the skewness values showed in the table indicate that the distribution of the index returns are not symmetrical, since they present excess of kurtosis and fatter tails, being characterized as leptokurtic. 
Table 1. Descriptive statistics of the index return series

\begin{tabular}{|c|c|c|c|c|c|c|c|c|}
\hline & $\begin{array}{l}\text { Argent. } \\
\text { ADR }\end{array}$ & $\begin{array}{l}\text { Argent. } \\
\text { Market }\end{array}$ & $\begin{array}{l}\text { Brazil } \\
\text { ADR }\end{array}$ & $\begin{array}{c}\text { Brazil } \\
\text { Market }\end{array}$ & $\begin{array}{l}\text { Chile } \\
\text { ADR }\end{array}$ & $\begin{array}{c}\text { Chile } \\
\text { Market }\end{array}$ & $\begin{array}{c}\text { Mexico } \\
\text { ADR }\end{array}$ & $\begin{array}{l}\text { Mexico } \\
\text { Market }\end{array}$ \\
\hline Mean & 0.0000455 & 0.000873 & -0.000395 & -0.000175 & 0.000141 & 0.000156 & 0.0000922 & 0.000184 \\
\hline Median & 0.000404 & 0.000108 & 0 & 0 & 0 & 0 & 0.0000588 & 0.0000048 \\
\hline Maximum & 0.139237 & 0.104316 & 0.256391 & 0.136766 & 0.242345 & 0.118034 & 0.157257 & 0.104407 \\
\hline Minimum & -0.123121 & -0.129516 & -0.229762 & -0.120961 & -0.108151 & -0.072363 & -0.110277 & -0.072661 \\
\hline Standard Deviation & 0.020051 & 0.021325 & 0.025964 & 0.01806 & 0.016707 & 0.010415 & 0.017464 & 0.012793 \\
\hline Skewness & -0.617683 & -0.585681 & -0.12798 & 0.0821 & 1.404604 & 0.1994 & 0.078518 & 0.241867 \\
\hline Kurtosis (K) & 8.178878 & 7.24701 & 17.67994 & 10.60998 & 34.02517 & 17.37798 & 12.24224 & 11.52344 \\
\hline Sum & 0.082847 & 1.588572 & -0.719233 & -0.319115 & 0.256724 & 0.28287 & 0.167794 & 0.335085 \\
\hline$\Sigma(\text { Deviation })^{2}$ & 0.7309 & 0.826755 & 1.225524 & 0.592983 & 0.507465 & 0.197204 & 0.554448 & 0.297514 \\
\hline Observations & 1819 & 1819 & 1819 & 1819 & 1819 & 1819 & 1819 & 1819 \\
\hline & \multicolumn{2}{|r|}{ USA } & \multicolumn{2}{|c|}{ France } & \multicolumn{2}{|c|}{ Japan } & \multicolumn{2}{|c|}{ UK } \\
\hline Mean & \multicolumn{2}{|c|}{0.000225} & \multicolumn{2}{|c|}{-0.000000701} & \multicolumn{2}{|c|}{0.000198} & \multicolumn{2}{|c|}{0.0000786} \\
\hline Median & \multicolumn{2}{|c|}{0.000422} & \multicolumn{2}{|c|}{0.000208} & \multicolumn{2}{|c|}{0} & \multicolumn{2}{|c|}{0.000133} \\
\hline Maximum & \multicolumn{2}{|c|}{0.109572} & \multicolumn{2}{|c|}{0.105946} & \multicolumn{2}{|c|}{0.132346} & \multicolumn{2}{|c|}{0.093842} \\
\hline Minimum & \multicolumn{2}{|c|}{-0.094695} & \multicolumn{2}{|c|}{-0.094715} & \multicolumn{2}{|c|}{-0.12111} & \multicolumn{2}{|c|}{-0.092645} \\
\hline Standard Deviation & \multicolumn{2}{|c|}{0.014054} & \multicolumn{2}{|c|}{0.015832} & \multicolumn{2}{|c|}{0.016352} & \multicolumn{2}{|c|}{0.012869} \\
\hline Skewness & \multicolumn{2}{|c|}{-0.339459} & \multicolumn{2}{|c|}{0.117885} & \multicolumn{2}{|c|}{-0.589823} & \multicolumn{2}{|c|}{-0.111374} \\
\hline Kurtosis (K) & \multicolumn{2}{|c|}{13.34321} & \multicolumn{2}{|c|}{8.985982} & \multicolumn{2}{|c|}{12.38618} & \multicolumn{2}{|c|}{11.78826} \\
\hline Sum & \multicolumn{2}{|c|}{0.408707} & \multicolumn{2}{|c|}{-0.001275} & & 055 & 0.1 & 042 \\
\hline$\Sigma(\text { Deviation })^{2}$ & & 359099 & & 55661 & & 6141 & 0.3 & 063 \\
\hline Observations & & 1819 & & 819 & & 19 & & \\
\hline
\end{tabular}

Figure 2 shows the behaviors of the daily returns of the twelve time series over the period from June/2008 to May/2015. It is verified that the return graphs present an oscillation around the value of zero. It is also possible to observe the presence of volatility clustering at some moments. The most significant one and that was present in all the indices took place in the period between the second half of 2008 and the first half of 2009 , when the subprime crisis reached its climax. There is also another clustering present on the second half of 2011 in most of the indices, which correponds to the moment in which the debt problem in countries of the Euro Zone rebounded in the international markets, both in the developed and developing ones, in this case, those of Latin America.

\section{RESULTS}

\subsection{INTERDEPENDENCE PHENOMENON}

For the multivaried asymmetric VAR-MGARCH I and II models, the coefficients of the equation of the conditional mean of return are found in tables 2 and 3, respectively.

Clearly, the United States appeared to be the most influencing country. There were return spillovers from its market to all the developed ones as well as to the four ADR indices of Latin America and to the market index of Chile. In turn, France was also able to impact the other developed ones and the market index of Chile, but it did not have significant influence on the ADR indices. 
BBR

15,4

399

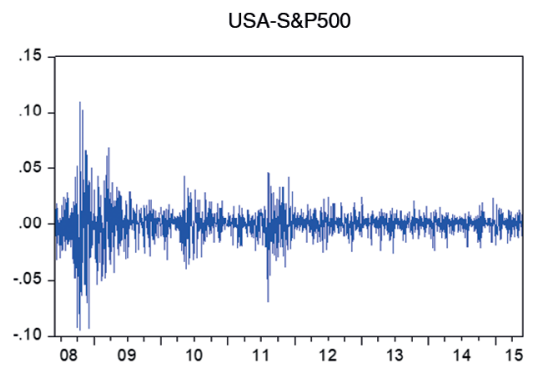

Japan-NIKKEI225
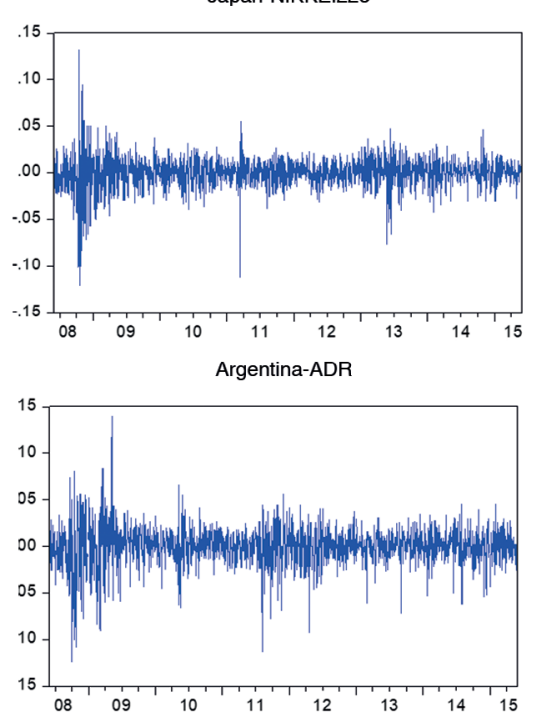

Chile-ADR
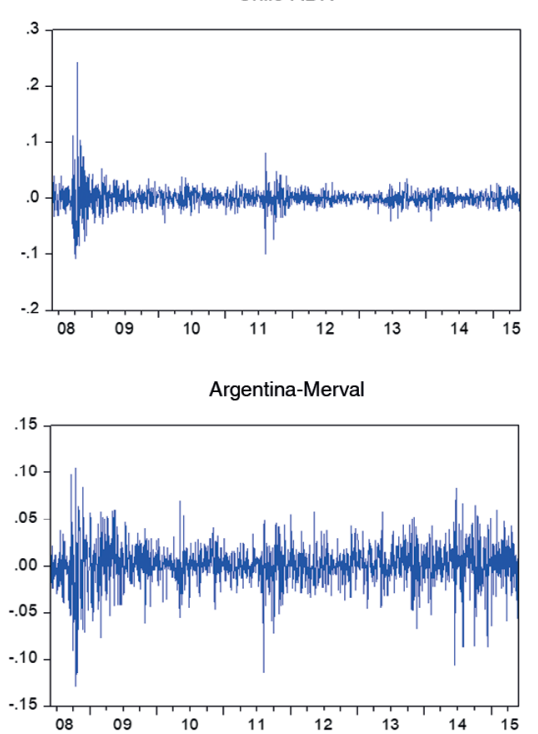

Chile-IPSA

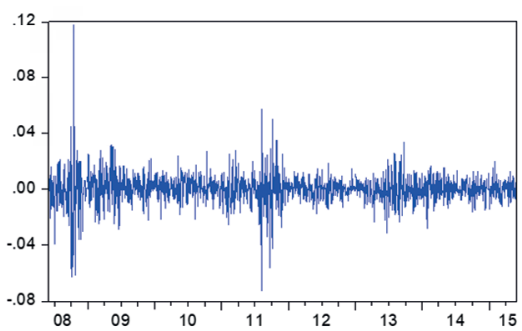

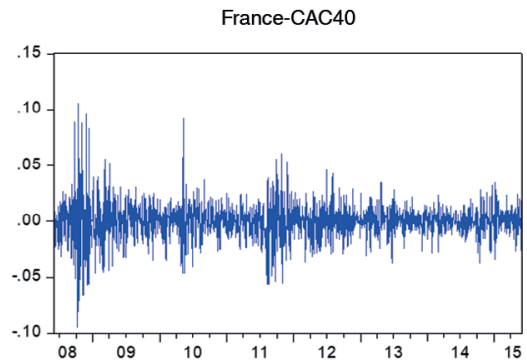

United Kingdom-FTSE100
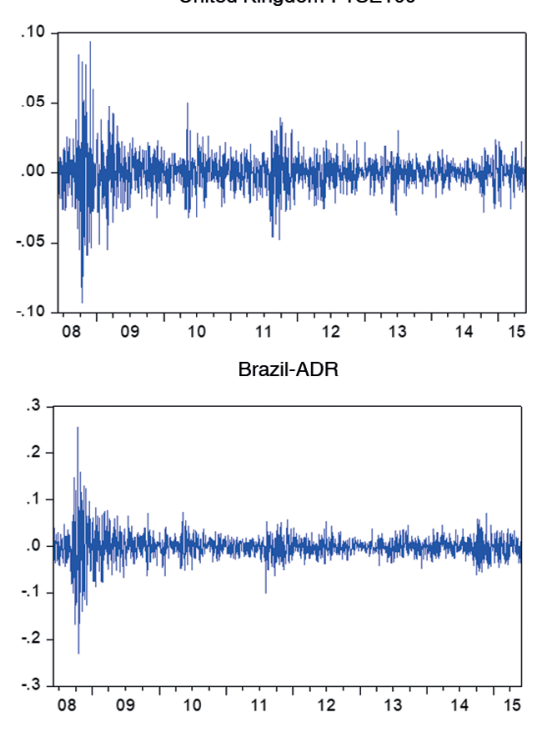

Mexico-ADR
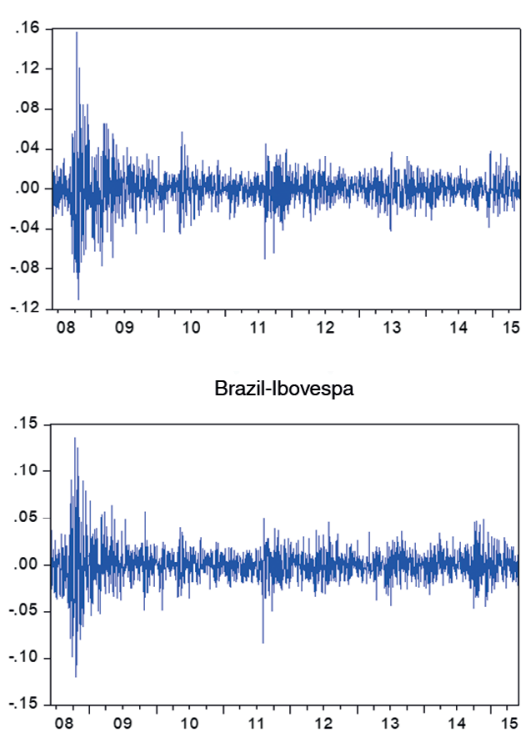

Mexico-IPC

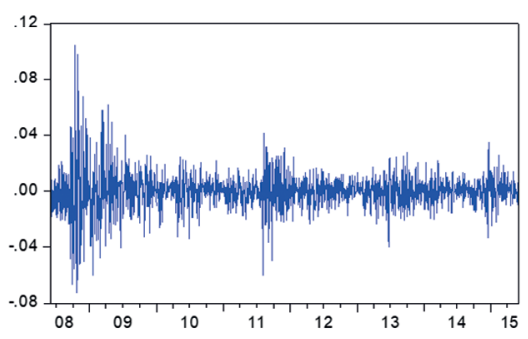

Figure 2. Graphs of the behavior of the daily log returns. 
Table 2. Coefficients of the equations of conditional mean of return - Model I

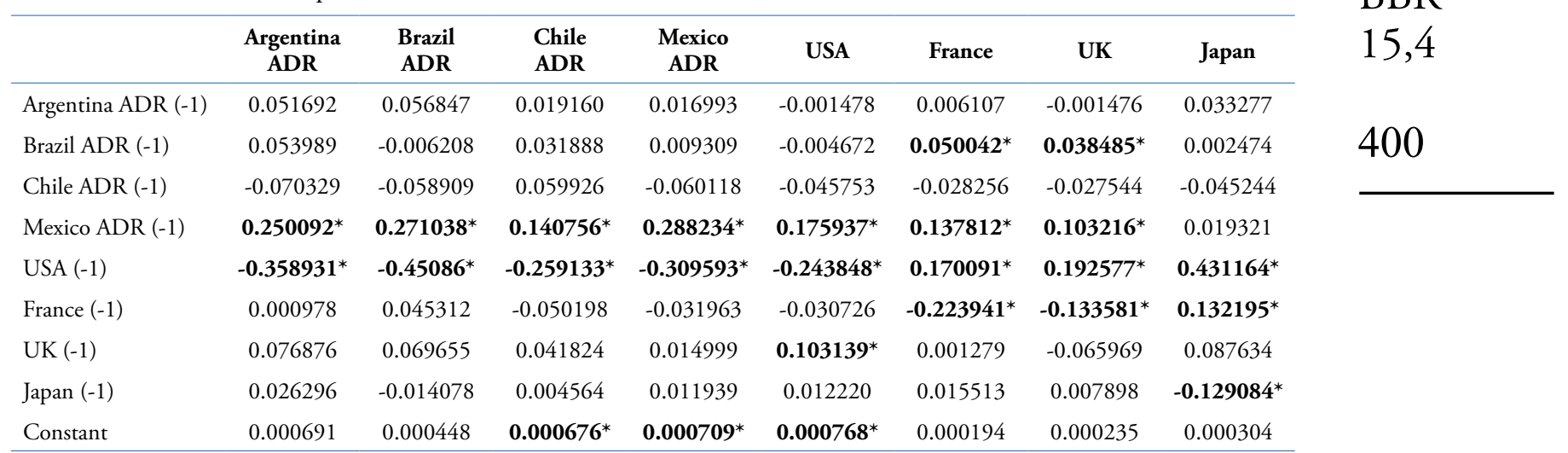

* Significant coefficients at the $5 \%$ level of significance.

Table 3. Coefficients of the equations of conditional mean of return - Model II

\begin{tabular}{|c|c|c|c|c|c|c|c|c|}
\hline & $\begin{array}{c}\text { Argentina } \\
\text { Market }\end{array}$ & $\begin{array}{c}\text { Brazil } \\
\text { Market }\end{array}$ & $\begin{array}{l}\text { Chile } \\
\text { Market }\end{array}$ & $\begin{array}{l}\text { Mexico } \\
\text { Market }\end{array}$ & USA & France & UK & Japan \\
\hline Argentina Market $(-1)$ & 0.020310 & -0.020665 & 0.011431 & 0.004413 & -0.020427 & -0.017101 & -0.018781 & 0.027072 \\
\hline Brazil Market (-1) & 0.017689 & $-0.100426^{*}$ & 0.016638 & -0.011605 & 0.003523 & 0.021679 & 0.030060 & 0.001818 \\
\hline Chile Market (-1) & 0.002360 & 0.032155 & $0.152492^{*}$ & -0.013422 & -0.041975 & -0.046078 & -0.016898 & 0.021577 \\
\hline Mexico Market (-1) & $0.193148^{*}$ & $0.139319^{*}$ & 0.039879 & $0.122005^{*}$ & $0.125813^{*}$ & $0.144736^{*}$ & $0.099292^{*}$ & 0.052890 \\
\hline USA $(-1)$ & 0.041093 & 0.053885 & $0.070925^{*}$ & 0.051267 & $-0.088512^{*}$ & $0.361995^{*}$ & $0.330331^{*}$ & $0.424733^{*}$ \\
\hline France $(-1)$ & -0.057053 & -0.051416 & $-0.088397^{*}$ & -0.055548 & $-0.070762^{*}$ & $-0.285959^{*}$ & $-0.176473^{*}$ & 0.072239 \\
\hline $\mathrm{UK}(-1)$ & -0.006419 & 0.087212 & 0.012174 & -0.007755 & $0.109026^{*}$ & 0.016701 & -0.068210 & $0.141759^{*}$ \\
\hline Japan $(-1)$ & 0.047864 & -0.032076 & -0.011925 & -0.002267 & 0.000072 & 0.003135 & -0.007826 & $-0.140288^{*}$ \\
\hline Constant & $0.001037^{*}$ & 0.000385 & 0.000298 & $0.000521^{*}$ & $0.000737^{*}$ & 0.000266 & 0.000199 & 0.000351 \\
\hline
\end{tabular}

The actual spillover of returns were present in the following markets: Mexico ADR index and the market indices of Brazil, Chile, Mexico, the United States, France and Japan. That means that, in these markets, the $\mathrm{t}-1$ returns are predictors of returns in $\mathrm{t}$ for their own indices.

The coefficients of the conditional variance and covariance equations are shown in tables 4 and 5 for the VECH MGARCH I and II DiagonalVECH models, respectively.

We can observe that the Al coefficients of all the index pairs were positive and significant at a $5 \%$ significance level. That means that the volatility spillovers are positively correlated between the markets, that is, a shock in a market tends to increase the volatility in another one. In turn, the presence of the statistically significant B1 coefficients in the model, corresponding to the GARCH terms, indicate that the conditional volatility of a certain market depends on past conditional volatilities. Thus, it measures the volatility persistence level in the model. We can also observe that the impact of the ARCH (A1) terms is considerably lower compared to the GARCH (B1) terms in a market volatility forecast. It is an indication that, in these markets, the past volatility has greater predictive power on the current volatility than the past shocks or innovations of the returns (errors).

The values highlighted in the diagonal of the matrixes A $(i, n)$ and $B(i, n)$ reveal the so called own-volatility spillovers, that is, how values of past shocks and a market volatility impact its own current variance. This phenomenon was present in all the markets in an expressive way. Nevertheless, in general, it presented greater intensity in the Latin American countries than in the developed ones, both considering the ADR indices and the market indices. 
BBR

15,4

401

Table 4. Asymmetric MGARCH Diagonal VECH model: Model I

\begin{tabular}{|c|c|c|c|c|c|c|c|c|}
\hline & $\begin{array}{c}\text { Arg. ADR } \\
(\mathrm{i}=1)\end{array}$ & $\begin{array}{l}\text { Brazil ADR } \\
\quad(\mathrm{i}=2)\end{array}$ & $\begin{array}{c}\text { Chile ADR } \\
\text { (i=3) }\end{array}$ & $\begin{array}{c}\text { Mexico ADR } \\
(\mathrm{i}=4)\end{array}$ & $\begin{array}{l}\text { USA } \\
(\mathrm{i}=5)\end{array}$ & $\begin{array}{c}\text { France } \\
(\mathrm{i}=6)\end{array}$ & $\begin{array}{c}\text { UK } \\
(\mathbf{i}=7) \\
\end{array}$ & $\begin{array}{c}\text { Japan } \\
(\mathrm{i}=8)\end{array}$ \\
\hline$M(i, 1)$ & $1.42 \mathrm{E}-05$ & $8.81 \mathrm{E}-06$ & $6.21 \mathrm{E}-06$ & $6.33 \mathrm{E}-06$ & 5.39E-06 & $6.81 \mathrm{E}-06$ & $5.04 \mathrm{E}-06$ & $6.25 \mathrm{E}-06$ \\
\hline $\mathrm{M}(\mathrm{i}, 2)$ & $8.81 \mathrm{E}-06$ & $1.05 \mathrm{E}-05$ & $5.70 \mathrm{E}-06$ & $6.09 \mathrm{E}-06$ & $5.02 \mathrm{E}-06$ & $5.83 \mathrm{E}-06$ & $4.81 \mathrm{E}-06$ & 4.23E-06 \\
\hline $\mathrm{M}(\mathrm{i}, 3)$ & $6.21 \mathrm{E}-06$ & $5.70 \mathrm{E}-06$ & $5.82 \mathrm{E}-06$ & $4.37 \mathrm{E}-06$ & $3.78 \mathrm{E}-06$ & $4.80 \mathrm{E}-06$ & $3.90 \mathrm{E}-06$ & $3.50 \mathrm{E}-06$ \\
\hline $\mathrm{M}(\mathrm{i}, 4)$ & $6.33 \mathrm{E}-06$ & $6.09 \mathrm{E}-06$ & 4.37E-06 & $6.41 \mathrm{E}-06$ & $4.28 \mathrm{E}-06$ & $4.12 \mathrm{E}-06$ & $3.31 \mathrm{E}-06$ & $3.70 \mathrm{E}-06$ \\
\hline$M(i, 5)$ & $5.39 \mathrm{E}-06$ & $5.02 \mathrm{E}-06$ & $3.78 \mathrm{E}-06$ & $4.28 \mathrm{E}-06$ & $4.07 \mathrm{E}-06$ & $4.29 \mathrm{E}-06$ & $3.27 \mathrm{E}-06$ & $4.15 \mathrm{E}-06$ \\
\hline$M(i, 6)$ & $6.81 \mathrm{E}-06$ & $5.83 \mathrm{E}-06$ & $4.80 \mathrm{E}-06$ & $4.12 \mathrm{E}-06$ & $4.29 \mathrm{E}-06$ & $6.20 \mathrm{E}-06$ & $3.93 \mathrm{E}-06$ & $3.20 \mathrm{E}-06$ \\
\hline $\mathrm{M}(\mathrm{i}, 7)$ & $5.04 \mathrm{E}-06$ & $4.81 \mathrm{E}-06$ & $3.90 \mathrm{E}-06$ & $3.31 \mathrm{E}-06$ & $3.27 \mathrm{E}-06$ & $3.93 \mathrm{E}-06$ & $2.89 \mathrm{E}-06$ & $2.12 \mathrm{E}-06$ \\
\hline$M(i, 8)$ & $6.25 \mathrm{E}-06$ & $4.23 \mathrm{E}-06$ & $3.50 \mathrm{E}-06$ & $3.70 \mathrm{E}-06$ & $4.15 \mathrm{E}-06$ & $3.20 \mathrm{E}-06$ & $2.12 \mathrm{E}-06$ & 7.94E-06 \\
\hline $\mathrm{A} 1(\mathrm{i}, 1)$ & 0.110463 & 0.080747 & 0.095527 & 0.073345 & 0.091315 & 0.073286 & 0.076230 & 0.068577 \\
\hline $\mathrm{A} 1(\mathrm{i}, 2)$ & 0.080747 & 0.075480 & 0.086848 & 0.070652 & 0.085905 & 0.067914 & 0.074104 & 0.056236 \\
\hline $\mathrm{A} 1(\mathrm{i}, 3)$ & 0.095527 & 0.086848 & 0.105459 & 0.084340 & 0.103733 & 0.089618 & 0.088032 & 0.082033 \\
\hline $\mathrm{A} 1(\mathrm{i}, 4)$ & 0.073345 & 0.070652 & 0.084340 & 0.069066 & 0.080589 & 0.051358 & 0.057582 & 0.058742 \\
\hline $\mathrm{A} 1(\mathrm{i}, 5)$ & 0.091315 & 0.085905 & 0.103733 & 0.080589 & 0.088117 & 0.079966 & 0.079763 & 0.064944 \\
\hline $\mathrm{A} 1(\mathrm{i}, 6)$ & 0.073286 & 0.067914 & 0.089618 & 0.051358 & 0.079966 & 0.055479 & 0.056065 & 0.038461 \\
\hline $\mathrm{A} 1(\mathrm{i}, 7)$ & 0.076230 & 0.074104 & 0.088032 & 0.057582 & 0.079763 & 0.056065 & 0.044611 & 0.055341 \\
\hline $\mathrm{A} 1(\mathrm{i}, 8)$ & 0.068577 & 0.056236 & 0.082033 & 0.058742 & 0.064944 & 0.038461 & 0.055341 & 0.109575 \\
\hline $\mathrm{D} 1(\mathrm{i}, 1)$ & $-0.019802^{*}$ & $-0.008605^{*}$ & $-0.001820^{*}$ & $-0.002798^{*}$ & $-0.005127^{*}$ & $0.000339^{*}$ & $-0.005694^{*}$ & $-0.027368^{*}$ \\
\hline $\mathrm{D} 1(\mathrm{i}, 2)$ & $-0.008605^{*}$ & $-0.001642^{*}$ & $-0.000148^{*}$ & $-0.000417^{*}$ & $-0.004869^{*}$ & $-0.001548^{*}$ & $-0.013310^{*}$ & $-0.017108^{*}$ \\
\hline $\mathrm{D} 1(\mathrm{i}, 3)$ & $-0.001820^{*}$ & $-0.000148^{*}$ & $-0.001977^{*}$ & $-0.002015^{*}$ & $-0.001756^{*}$ & $-0.003745^{*}$ & $-0.005278^{*}$ & $0.001553^{*}$ \\
\hline D1 $(\mathrm{i}, 4)$ & $-0.002798^{*}$ & $-0.000417^{*}$ & $-0.002015^{*}$ & $0.012108^{*}$ & $0.005157^{*}$ & $0.008215^{*}$ & $-0.002997^{*}$ & $-0.008827^{*}$ \\
\hline D1 $(i, 5)$ & $-0.005127^{*}$ & $-0.004869^{*}$ & $-0.001756^{*}$ & $0.005157^{*}$ & 0.023 & $-0.004170^{*}$ & $-0.009483^{*}$ & $-0.017046^{*}$ \\
\hline $\mathrm{D} 1(\mathrm{i}, 6)$ & $0.000339^{*}$ & $-0.001548^{*}$ & $-0.003745^{*}$ & $0.008215^{*}$ & $-0.004170^{*}$ & 0.046164 & 0.035994 & $0.014031^{*}$ \\
\hline D1 $(i, 7)$ & $-0.005694^{*}$ & $-0.013310^{*}$ & $-0.005278^{*}$ & $-0.002997^{*}$ & $-0.009483^{*}$ & 0.035994 & 0.045098 & $0.000191^{*}$ \\
\hline D1 $(\mathrm{i}, 8)$ & $-0.027368^{*}$ & $-0.017108^{*}$ & $0.001553^{*}$ & $-0.008827^{*}$ & $-0.017046^{*}$ & $0.014031^{*}$ & $0.000191^{*}$ & 0.077128 \\
\hline $\mathrm{B} 1(\mathrm{i}, 1)$ & 0.866351 & 0.884957 & 0.857594 & 0.885879 & 0.869415 & 0.865678 & 0.867492 & 0.760704 \\
\hline $\mathrm{B} 1(\mathrm{i}, 2)$ & 0.884957 & 0.897821 & 0.878966 & 0.895916 & 0.882357 & 0.881519 & 0.877461 & 0.795123 \\
\hline $\mathrm{B} 1(\mathrm{i}, 3)$ & 0.857594 & 0.878966 & 0.867911 & 0.877006 & 0.855501 & 0.845339 & 0.844253 & 0.692562 \\
\hline $\mathrm{B} 1(\mathrm{i}, 4)$ & 0.885879 & 0.895916 & 0.877006 & 0.891777 & 0.877198 & 0.896743 & 0.892563 & 0.790631 \\
\hline $\mathrm{B} 1(\mathrm{i}, 5)$ & 0.869415 & 0.882357 & 0.855501 & 0.877198 & 0.865942 & 0.867632 & 0.867881 & 0.717353 \\
\hline $\mathrm{B} 1(\mathrm{i}, 6)$ & 0.865678 & 0.881519 & 0.845339 & 0.896743 & 0.867632 & 0.885043 & 0.888688 & 0.842009 \\
\hline $\mathrm{B} 1(\mathrm{i}, 7)$ & 0.867492 & 0.877461 & 0.844253 & 0.892563 & 0.867881 & 0.888688 & 0.903114 & 0.847052 \\
\hline $\mathrm{B} 1(\mathrm{i}, 8)$ & 0.760704 & 0.795123 & 0.692562 & 0.790631 & 0.717353 & 0.842009 & 0.847052 & 0.811803 \\
\hline
\end{tabular}

* No statistical significance at the $5 \%$ level.

Regarding the skewness in the volatility spillovers, only some coefficients D1 (TARCH) were statistically significant at the $5 \%$ level. For these indices, specially, the return volatility tends to be greater in response to negative shocks than to positive ones. This effect was present mainly in the own-volatility spillovers of the developed markets, and it was observed in the markets of the United States, France, the United Kingdom and Japan. On the other hand, in the Latin American markets, just the Chilean market index presented this effect. In turn, in the volatility spillovers, the skewness was relevant only for what happens between France and the United Kingdom. Another finding is that the relative skewness magnitude was greater in the own spillovers than in the volatility spillovers between the markets, and Japan was the country with the steepest skewness in own spillovers.

Finally, we performed an analysis of the daily conditional correlations between each pair of variables, resulting from the models. Table 6 shows a summary of its main characteristics. 
Table 5. Asymmetric MGARCH Diagonal VECH model: Model II

\begin{tabular}{|c|c|c|c|c|c|c|c|c|}
\hline & $\underset{(\mathrm{i}=1)}{\operatorname{Arg} . \text { Market }}$ & $\begin{array}{c}\text { Brazil Market } \\
\quad(\mathbf{i}=2)\end{array}$ & $\begin{array}{c}\text { Chile Market } \\
\quad(\mathrm{i}=3)\end{array}$ & $\begin{array}{c}\text { Mexico Market } \\
(\mathbf{i}=4)\end{array}$ & $\begin{array}{l}\text { USA } \\
(\mathrm{i}=5)\end{array}$ & $\begin{array}{c}\text { France } \\
(\mathbf{i}=6)\end{array}$ & $\begin{array}{c}\text { UK } \\
(\mathbf{i}=7)\end{array}$ & $\begin{array}{c}\text { Japan } \\
(\mathrm{i}=8)\end{array}$ \\
\hline $\mathrm{M}(\mathrm{i}, 1)$ & $1.36 \mathrm{E}-05$ & $5.55 \mathrm{E}-06$ & $2.64 \mathrm{E}-06$ & $3.57 \mathrm{E}-06$ & $3.98 \mathrm{E}-06$ & $6.18 \mathrm{E}-06$ & $3.67 \mathrm{E}-06$ & $3.57 \mathrm{E}-06$ \\
\hline$M(i, 2)$ & $5.55 \mathrm{E}-06$ & $5.63 \mathrm{E}-06$ & $2.66 \mathrm{E}-06$ & $2.28 \mathrm{E}-06$ & $3.37 \mathrm{E}-06$ & $3.63 \mathrm{E}-06$ & $2.56 \mathrm{E}-06$ & $1.91 \mathrm{E}-06^{*}$ \\
\hline$M(i, 3)$ & $2.64 \mathrm{E}-06$ & $2.66 \mathrm{E}-06$ & $2.95 \mathrm{E}-06$ & $1.75 \mathrm{E}-06$ & $2.15 \mathrm{E}-06$ & $2.60 \mathrm{E}-06$ & $1.74 \mathrm{E}-06$ & $1.36 \mathrm{E}-06^{*}$ \\
\hline$M(i, 4)$ & 3.57E-06 & $2.28 \mathrm{E}-06$ & $1.75 \mathrm{E}-06$ & $2.05 \mathrm{E}-06$ & $2.61 \mathrm{E}-06$ & $2.51 \mathrm{E}-06$ & $1.78 \mathrm{E}-06$ & $1.94 \mathrm{E}-06$ \\
\hline$M(i, 5)$ & $3.98 \mathrm{E}-06$ & $3.37 \mathrm{E}-06$ & $2.15 \mathrm{E}-06$ & $2.61 \mathrm{E}-06$ & 4.07E-06 & 4.24E-06 & $2.87 \mathrm{E}-06$ & $2.43 \mathrm{E}-06^{*}$ \\
\hline$M(i, 6)$ & $6.18 \mathrm{E}-06$ & $3.63 \mathrm{E}-06$ & $2.60 \mathrm{E}-06$ & $2.51 \mathrm{E}-06$ & $4.24 \mathrm{E}-06$ & $6.61 \mathrm{E}-06$ & 3.77E-06 & 2.94E-06 \\
\hline $\mathrm{M}(\mathrm{i}, 7)$ & $3.67 \mathrm{E}-06$ & $2.56 \mathrm{E}-06$ & $1.74 \mathrm{E}-06$ & $1.78 \mathrm{E}-06$ & $2.87 \mathrm{E}-06$ & $3.77 \mathrm{E}-06$ & $2.52 \mathrm{E}-06$ & $1.98 \mathrm{E}-06$ \\
\hline$M(i, 8)$ & $3.57 \mathrm{E}-06$ & $1.91 \mathrm{E}-06^{*}$ & $1.36 \mathrm{E}-06^{*}$ & $1.94 \mathrm{E}-06$ & $2.43 \mathrm{E}-06^{*}$ & $2.94 \mathrm{E}-06$ & $1.98 \mathrm{E}-06$ & 8.03E-06 \\
\hline $\mathrm{A} 1(\mathrm{i}, 1)$ & 0.103536 & 0.080382 & 0.082910 & 0.089068 & 0.073144 & 0.073634 & 0.059517 & 0.066560 \\
\hline $\mathrm{A} 1(\mathrm{i}, 2)$ & 0.080382 & 0.069869 & 0.080660 & 0.073511 & 0.084141 & 0.071196 & 0.060167 & 0.069661 \\
\hline $\mathrm{A} 1(\mathrm{i}, 3)$ & 0.082910 & 0.080660 & 0.091509 & 0.083605 & 0.098365 & 0.074203 & 0.057988 & 0.060568 \\
\hline A1 $(i, 4)$ & 0.089068 & 0.073511 & 0.083605 & 0.074026 & 0.088757 & 0.069212 & 0.060942 & 0.077127 \\
\hline A1 $(i, 5)$ & 0.073144 & 0.084141 & 0.098365 & 0.088757 & 0.084142 & 0.091704 & 0.068269 & 0.041302 \\
\hline A1 $(i, 6)$ & 0.073634 & 0.071196 & 0.074203 & 0.069212 & 0.091704 & 0.080809 & 0.062109 & 0.050177 \\
\hline $\mathrm{A} 1(\mathrm{i}, 7)$ & 0.059517 & 0.060167 & 0.057988 & 0.060942 & 0.068269 & 0.062109 & 0.040261 & 0.054803 \\
\hline $\mathrm{A} 1(\mathrm{i}, 8)$ & 0.066560 & 0.069661 & 0.060568 & 0.077127 & 0.041302 & 0.050177 & 0.054803 & 0.117799 \\
\hline $\mathrm{D} 1(\mathrm{i}, 1)$ & $0.012838^{*}$ & $-0.002310^{*}$ & $-0.003196^{*}$ & $0.001138^{*}$ & $0.006059^{*}$ & $0.005296^{*}$ & $0.007647^{*}$ & $-0.035276^{*}$ \\
\hline $\mathrm{D} 1(\mathrm{i}, 2)$ & $-0.002310^{*}$ & $0.001225^{*}$ & $0.004838^{*}$ & $0.003082^{*}$ & $-0.004167^{*}$ & $-0.001490^{*}$ & $0.003058^{*}$ & $-0.013633^{*}$ \\
\hline D1 $(i, 3)$ & $-0.003196^{*}$ & $0.004838^{*}$ & 0.048673 & $-0.004166^{*}$ & $-0.009560^{*}$ & $-0.000572^{*}$ & $0.011598^{*}$ & $-0.011851^{*}$ \\
\hline $\mathrm{D} 1(\mathrm{i}, 4)$ & $0.001138^{*}$ & $0.003082^{*}$ & $-0.004166^{*}$ & $0.001867^{*}$ & $-0.001935^{*}$ & $-0.006842^{*}$ & $-0.002930^{*}$ & $0.000852^{*}$ \\
\hline $\mathrm{D} 1(\mathrm{i}, 5)$ & $0.006059^{*}$ & $-0.004167^{*}$ & $-0.009560^{*}$ & $-0.001935^{*}$ & 0.035440 & $-0.005099^{*}$ & $0.002543^{*}$ & $-0.008475^{*}$ \\
\hline $\mathrm{D} 1(\mathrm{i}, 6)$ & $0.005296^{*}$ & $-0.001490^{*}$ & $-0.000572^{*}$ & $-0.006842^{*}$ & $-0.005099^{*}$ & $0.026429^{*}$ & 0.029586 & $0.000769^{*}$ \\
\hline $\mathrm{D} 1(\mathrm{i}, 7)$ & $0.007647^{*}$ & $0.003058^{*}$ & $0.011598^{*}$ & $-0.002930^{*}$ & $0.002543^{*}$ & 0.029586 & 0.047771 & $-0.013427^{*}$ \\
\hline D1 $(i, 8)$ & $-0.035276^{*}$ & $-0.013633^{*}$ & $-0.011851^{*}$ & $0.000852^{*}$ & $-0.008475^{*}$ & $0.000769^{*}$ & $-0.013427^{*}$ & 0.052991 \\
\hline $\mathrm{B} 1(\mathrm{i}, 1)$ & 0.865370 & 0.883806 & 0.875919 & 0.868882 & 0.884048 & 0.862724 & 0.881999 & 0.821542 \\
\hline $\mathrm{B} 1(\mathrm{i}, 2)$ & 0.883806 & 0.908445 & 0.862547 & 0.900445 & 0.881368 & 0.884804 & 0.892810 & 0.806272 \\
\hline B1(i,3) & 0.875919 & 0.862547 & 0.852483 & 0.870204 & 0.851146 & 0.863288 & 0.874675 & 0.792996 \\
\hline $\mathrm{B} 1(\mathrm{i}, 4)$ & 0.868882 & 0.900445 & 0.870204 & 0.912516 & 0.874645 & 0.894658 & 0.898284 & 0.787336 \\
\hline B1(i,5) & 0.884048 & 0.881368 & 0.851146 & 0.874645 & 0.864522 & 0.862471 & 0.879131 & 0.828228 \\
\hline B1(i,6) & 0.862724 & 0.884804 & 0.863288 & 0.894658 & 0.862471 & 0.872878 & 0.888956 & 0.848742 \\
\hline B1(i,7) & 0.881999 & 0.892810 & 0.874675 & 0.898284 & 0.879131 & 0.888956 & 0.909186 & 0.861255 \\
\hline B1(i,8) & 0.821542 & 0.806272 & 0.792996 & 0.787336 & 0.828228 & 0.848742 & 0.861255 & 0.817567 \\
\hline
\end{tabular}

* No statistical significance at the $5 \%$ level.

Table 6. Average of the conditional correlation between the indices - Models I and II

\begin{tabular}{|c|c|c|c|c|c|c|c|c|}
\hline & \multicolumn{4}{|c|}{ VAR-MGARCH I Model } & \multicolumn{4}{|c|}{ VAR-MGARCH II Model } \\
\hline & $\begin{array}{l}\text { ADRs x } \\
\text { ADRs }\end{array}$ & $\begin{array}{c}\text { ADRs x } \\
\text { Developed }\end{array}$ & $\begin{array}{l}\text { Developed x } \\
\text { Developed }\end{array}$ & Overall & $\begin{array}{l}\text { Latin America x } \\
\text { Latin America }\end{array}$ & $\begin{array}{c}\text { Latin America } \\
x \text { Developed }\end{array}$ & $\begin{array}{l}\text { Developed x } \\
\text { Developed }\end{array}$ & Overal \\
\hline Jun./Dec. 2008 & 0.658 & 0.422 & 0.394 & 0.467 & 0.516 & 0.384 & 0.396 & 0.415 \\
\hline Jan./Dec. 2009 & 0.689 & 0.488 & 0.434 & 0.520 & 0.565 & 0.421 & 0.436 & 0.455 \\
\hline Jan./Dec. 2010 & 0.694 & 0.510 & 0.472 & 0.541 & 0.514 & 0.428 & 0.470 & 0.455 \\
\hline Jan./Dec. 2011 & 0.713 & 0.512 & 0.462 & 0.544 & 0.518 & 0.418 & 0.460 & 0.448 \\
\hline Jan./Dec. 2012 & 0.635 & 0.498 & 0.467 & 0.521 & 0.418 & 0.398 & 0.465 & 0.417 \\
\hline Jan./Dec. 2013 & 0.571 & 0.423 & 0.439 & 0.458 & 0.367 & 0.323 & 0.434 & 0.356 \\
\hline Jan./Dec. 2014 & 0.569 & 0.434 & 0.457 & 0.468 & 0.380 & 0.336 & 0.450 & 0.370 \\
\hline Jan./Mai. 2015 & 0.622 & 0.398 & 0.448 & 0.457 & 0.439 & 0.338 & 0.446 & 0.383 \\
\hline Overall average & 0.644 & 0.461 & 0.447 & 0.497 & 0.465 & 0.381 & 0.445 & 0.412 \\
\hline
\end{tabular}


BBR

15,4

403

We can observe that the correlation increase from 2008 to 2009, period of the subprime crisis climax, in all the market groups. On average, in general, the correlations increased about $10 \%$ in 2009 , compared to those of the year before.

We can also observe that the ADR indices presented higer correlations with all the developed markets, whose average was 0.468 , in comparison to the indices of Latin American markets, whose average was 0.384 . The correlations between the Latin American markets, specially the ADR indices, and the United States are higher than those between these markets and the other developed countries.

Finally, the regional correlation among the Latin American countries were significant, mainly between the ADR indices, which presented an average of 0.66 , while this value was 0.46 for the market indices of these countries.

\section{DISCUSSION}

\subsection{CHARACTERISTICS OF THE INDICES}

All the indices presented some typical characteristics of financial return series, known as "stylized facts", which were: distribution of non-normal and asymmetric returns, excess of kurtosis, that is leptokurtic, with the presence of fatter tails. Nonetheless, despite being present in all the markets, the ADR indices had the highest skewness and kurtosis values. Moreover, all the series were weakly stationary and nonlinear, since their returns did not present independent and identically distributed behavior, indicating the existence of their time dependence. These results were the same found by most of the empirical studies in the field, for instance, Cont (2001) and Praetz (1972). Another aspect which was present in all the indices was the forming of volatility clustering over time. According to Ning, Xu \& Wirjanto (2015), this is a well-known stylized fact of asset financial returns.

The Latin American market indices presented greater return and risk compared to the developed countries. The reason is that, on average, their daily returns and standard deviation were higher to those of the second group. This finding is in accordance with the classical finance theory of return and risk, known as Markowitz Modern Portfolio Theory (1952), which pressuposes that the greater risk assets have higher returns. That was present in almost all the studies that assessed this aspect of developing markets, such as Bekaert \& Harvey's (1997) and Fayyad \& Daly's (2010). The exception was Brazil, whose mean return was the lowest of all, being, in fact negative, a fact that can be justified possibly due to internal problems faced by the country during that period.

On the other hand, the ADR indices, despite their average return had been lower than that of the market indices of their respective countries, showed higher mean volatility and, therefore, higher risk. That signals a spacing from the standard presented by the mature economies and it tends to go against what would be expected by the Markowitz Modern Portfolio Theory (1952), in which the greater risk assets should also present higher returns. One of the possible justifications for that would be the small number of companies and the great concentration present in the ADR indices in general, compared to the market indices, causing the fluctuations which occured in an isolated company, or in few of them, to have great impact on the overall index, resulting in higher volatility. There is also the fact the investors consider the market risk of both countries in the ADRs, which would rise their volatility in face of the indices of the countries singly. However, for a more concrete analysis of such statement, which goes against the theory, it would be necessary to add the beta of the companies as control variable. Thus, the systemmatic risk would be controlled, allowing just the market risk. 


\subsection{InTERdependence Phenomenon ANd ASymmetries}

The multivaried asymmetric VAR-MGARCH models, with Diagonal VECH representation, allowed capturing the spillover effects of both of the returns and the conditional volatility between the variables, in the case the indices of different markets, as well as their possible existing asymmetries.

Regarding the return spillovers, the North American market is the one that influences the other markets the most. There is this U.S. market effect in the four developed markets, as well as in the Latin American markets. A justification for this phenomenon is the trading volume of the U.S. market in comparison to the other countries'. It is worth highlighting Mexico, which had a great frequency of significant parameters, pointing out its influence in relation to the other Latin American countries. Nonetheless, it is observed that these have greater presence and with more intensity in the ADR indices in relation to the Latin America market indices. The reason is that there are U.S. return spillovers to all the ADR indices, while this phenomenon only happens for the Chilean market, among the stock indices of Latin American markets. The relationship of the U.S. index explaining the ADRs is also justified by an endogeny in these markets. Because the securities are traded in the same market, the investors tend to take the same market risk.

Moreover, in general, the ADR indices also presented more influence power on the others compared to the market indices, especially the Mexican one. Nevertheless, an interesting fact is that pratically there are no return spillovers from other developed countries to the Latin American markets, that is, the returns of the day before of the other mature economies do not impact the current returns of the Latin American markets significantly. The only exception is its existence from the French to the Chilean market index. That indicates that these other three markets - the British, French and Japanese - are less influent on Latin American countries.

We also found this ADR index relationship closer to the developed markets than the domestic ones in the study by Chandar et al. (2009). They found that the dual-listing companies react significantly to shocks accured in local markets in a less negative way than those that do not have DRs traded, particularly after the crisis. The results are consistent to the forecasts based on market segmentation theories as well as differentiated disclosure and governance standards between developed and developing markets. Boyer, Kumagai \& Yuan (2006), in a study carried out with developed and developing countries, despite not having used dual-listing companies, reached results that also confirmed those of this study. Separating the shares of developing markets in two categories, those which are elegible for purchase by foreign investors (accessible) and those which are not (non-accessible), their results showed greater co-movements for the returns of the accessible share indices, specially during periods of high volatility.

Thus, while the ADR indices are significantly influenced just by past U.S. returns and the Mexican ADR index, the Latin American market indices are more regionally influenced, by the Latin American countries themselves, than by the developed ones, since only Chile is impacted by past U.S. and French returns. Furthermore, the benefits of Latin American market diversification is confirmed. Morck, Yeung \& Yu (2000), in their empirical study, when comparing the behavior of developing and developed markets during financial crises, we also found out that the share prices move more jointly in poor economies than in the rich ones. In this regard, Valenzuela \& Rodríguez (2015) did not identify a strong volatility relationship between the United States and the rest of the Latin America in the period, except Mexico, which could suggest that the transmissions between the U.S.A. and the rest of the region is carried out through Mexico. This result is similar to that found in this 
BBR

15,4

study, in which Mexico was the most influent country among the Latin American ones. Specially its ADR index, since there were return spillovers from it to all the other ADR indices, as well as to the developed markets, but Japan. Several empirical studies also found return and volatility spillovers between developing and developed markets, and some found interdependence evidence, especially in the Latin America countries, such as those of Arouri, Bellalah \& Nguyen (2010), Barba \& Ceretta (2011) and Hwang (2014).

According to the results obtained by the MGARCH models, there were significant volatility spillovers in all the markets, indicating high existing interdependence between them in the period. Several empirical studies also found similar results, such as those by Rejeb \& Arfaoui (2016) and Valenzuela \& Rodríguez (2015). The reason is that, for all the index pairs, a shock occurred in the $t-1$ returns of a market tends to increase the volatility of another one in t. Moreover, the conditional volatility of a certain index depends on past conditional volatilities of others. This last phenomenon was more significant than the previous one in all the markets, indicating that the variance of the day before has greater predictive power on their current volatility than their past errors, that is, within them there is the presence of high volatility persistence level. This is the common result found in several empirical studies in the field, for instance, Syriopoulos, Makram \& Boubaker's (2015).

Similar to the the return spillovers, the volatility ones are also more regionally intense between the Latin American markets themselves than between those and the developed ones or between the developed ones themselves. That is valid considering both the ARCH or error coefficients or past innovations, such as past variance GARCH.

Comparing the ADR indices to the Latin American stock market ones, we observe that the volatility spillovers referring to past shocks (errors) between the ADR indices and the developed ones presented greater intensity, on average, than those of the other group. This result is in accordance with what was expected, due to, mainly, the closer relationship of the dual-listing companies to the mature economies, especially the United States, in relation to the other developing markets.

Another ascertainment is that the own-volatility spillovers in the markets are stronger than the spillovers between them. This fact indicated that the effects of shocks and lagged volatility persistence resulting from the market itself presented greater magnitude than those resulting from other markets, whether for the Latin American markets, or for the developed ones. This ascertainment is in accordance to what was detected by Rejeb \& Arfaoui (2016).

In general, similarly to the return spillovers, the United States presented the greatest effects of volatility spillovers with the others. On the other hand, the Japanese market was the one which had this effect the least.

Regarding the skewness of the volatility spillover, opposite to what was expected, just some indices presented this effect. It was present mainly in the own-volatility spillovers of developed markets. The market index of Chile was the only one of the Latin American ones that had this phenomenon. On the other hand, in the volatility spillovers, the skewness was relevant just in what occurs between France and the United Kingdom. Several empirical studies also found the existence of asymmetric co-movements in international capital markets of developed countries, such as Koutmos \& Booth (1995), Li (2014), among others. Nevertheless, contrary to this study results, some studies found this effect between developing and developed markets - Pagán \& Soydemir's (2001) and Rejeb \& Arfaoui's (2016) identified this phenomenon specifically between the countries of Latin America.

By the analysis of the conditional correlations resulting from the VAR-MGARCH models, we observe that such values between the developed markets, in general, were higher to those obtained between the Latin American markets and the developed ones, as expected theorically. It confirms the benefit of international portfolio diversification via 
financial assets of Latin America, even during an international financial crisis, like the subprime one.

On the other hand, the ADR indices clearly presented the greatest correlations among themselves and with the developed ones, corroborating the hypothesis that, due to their characteristics, their returns are closer to those of mature economies than to the others of Latin America. This effect is more significant between the ADR indices and the U.S.A., and of these, the Mexico ADR index was the one with the greatest correlation with the United States. In turn, the regional correlation between the countries of Latin America were greater than between the Latin American markets and the developed ones.

Finally, when analyzing the evolution of the conditional correlations between the index groups over time, we can observe that there was a rise from 2008 to 2009, period of the climax of the subprime crisis, in all the markets. This result is in accordance with what was expected, since, theoretically, the correlations between markets tend to increase in periods of crisis, as this one, as pointed by several studies, for instance, those by Arouriet al. (2010) and Hwang (2014). From 2009 to 2010, they were still high, with a general increase of $2 \%$. Although the aim of this study was not to identify the existence of contagion between the markets, this result indicates the existence of this phenomenon for these index groups in this period, deserving further future study. In 2011, they were basically in the same level, while in 2012 and 2013, all the index groups had a drop in these relationships. On average, they fell 18\% from 2011 to 2013 . That indicates that, probably, there was no contagion in these markets during the climax of the Euro Zone crisis, despite this conclusion it also requires further analysis. In 2014, they started to slightly rise, since, in general, they increased about $3 \%$. Finally, in 2015, the results were mixed for the index groups.

\section{CONCLUSION}

The main conclusion of this study is that the ADR indices have more interdependence with the main developed markets because they behave more closely to them, compared to the Latin American markets analyzed, regarding the subprime international financial crisis. This conclusion can be justified by the market segmentation theory and by the own characteristics of these companies. Therefore, the ADR indices receive more influence from the developed markets, mainly the United States, and impact more significantly these markets, notably the Mexican ADR index in this aspect, compared to the Latin American market indices. Still in this context, these indices of dual-listing companies have greater conditional correlations to the developed ones and more intense return and volatility spillovers with this group of countries, despite presenting less volatility persistence. Moreover, their own-volatility spillovers have more intensity than the other market indices.

Another relevant conclusion on the results obtained is that, as expected, the main developing markets of Latin America differ from the developed ones in relation to several factors on the behavior of their return series, as well as for the interdependence phenomenon and asymmetries. In general, they receive and exert more regional influence, from the Latin American capital markets themselves than from the developed countries, indicating that the interdependence between these two country groups, despite existing and being significant, mainly at moments of crisis climax, is lower than that existing regionally between the Latin American countries themselves or that which exists between the developed countries themselves. That shows the developing countries of Latin America are more susceptible to local and regional effects than to global ones and it confirms the benefit of the use of the financial assets of these markets for diversification of international portfolios, even in case of an international financial crisis, like the subprime one. 
BBR

15,4
For future research, we suggest to evaluate the price behavior for other developing countries or, even, to carry out a study with just the BRICS (Brazil, Russia, India, China and South Africa), which have had outstood in the worldwide economy from 2010. Also, analyze these effects in the Latin American countries, but altering the weights of the ADR index, considering the effect of foreign investment in the companies, which comprise the indices, since a large number of these companies have high investment from North American investors, funds and banks. In addition, even add some control variables in the GARCH and MGARCH models, which justify the results. For instance, a variable of trade negotiation volume, external capital participation and beta of companies. Maybe the volume is one of the main causers of greater U.S. interdependence, and the beta would control the non-diversified risk effect, allowing only the risk market in the analysis.

\section{REFERENCES}

ALOUI, C. Latin American stock markets' volatility spillovers during the financial crises: a multivariate FIAPARCHDCC framework. In: EMG Conference on Emerging Markets Finance, 3., 2011, London. Anais... London: Cass Business School, 2011. p. 1-34.

ARORA, R. K.; JAIN, P. K.; DAS, H. Behaviour of stock returns in selected emerging markets. Journal of Financial Management and Analysis, v. 22, n. 2, p. 13-25, 2009.

AROURI, M. E. H.;BELLALAH, M.; NGUYEN, D, K. The comovements in international stock markets: new evidence from Latin American emerging countries. Applied Economics Letters, v. 17, n. 13, p. 1323-1328, 2010.

BAE, K.; KAROLYI, G. A.; STULZ, R. M. A new approach to measuring financial contagion. Review of Financial studies, v. 16, n. 3, p. 717-763, 2003.

BARBA, F. G.; CERETTA, P. S. Risk transmission between Latin America stock markets and the US: impacts of the 2007/2008 Crisis. Economics Bulletin, v, 31, n 2, p.1025-1037, 2011.

BEIRNE, J.; CAPORALE, G. M.; SCHULZE-GHATTAS, M.; SPAGNOLO, N. Global and regional spillovers in emerging stock markets: A multivariate GARCH-in-mean analysis. Emerging Markets Review, v. 11, p. 250-260, 2010.

BEKAERT, G.; HARVEY, C. R. Emerging equity market volatility. Journal of Financial Economics, v. 43, p. 29-77, 1997.

BOLlERSLEV, T.; ENGLE, R.; WOOLDRIDGE, J. M. A capital asset pricing model with time varying co-variances. Journal of Political Economy, v. 96, n.1, p.116-131, 1988.

BOYER, B. H.; KUMAGAI, T.; YUAN, K. How do crises spread? Evidence from accessible and inaccessible stock indices. The Journal of Finance, v. 61, n 2, p. 957-1003, 2006.

CALVO, S.; REINHART, C. M. Capital flows to Latin America: Is there evidence of contagion effects? MPRA Working Paper, n. 7124, p. 1-25, 1996.

CHANDAR, N.; PATRO, D. K.; YEZEGEL, A. Crises, contagion and cross-listings. Journal of Banking \& Finance, v. 33, n 9, p. 1709-1729, 2009

CHUKWUOGOR, C.; FERIDUN, M. Recent emerging and developed European stock markets volatility of returns. European Journal of Finance and Banking Research, v. 1, n. 1, p. 28-46, 2007.

CONT, R. Empirical properties of asset returns: stylized facts and statistical issues. Quantitative Finance, v. 1, p. $223-236,2001$

CORONADO, S.; ROJAS, O.; ROMERO-MEZA, R.; VENEGAS-MARTÍNEZ, F. A study of co-movements between U.S. and Latin American stock markets: A cross-bicorrelations perspective. DYNA, Universidad Nacional de Colombia, v. 83, n. 196, p. 143-148, April 2016.

FAYYAD, A.; DALY, K. The volatility of market returns: a comparative study of emerging versus mature markets. International Journal of Business Management, v. 5, n 7, p. 24-36, 2010.

FANTO, J. A.; KARMEL, R. S. A Report on the Attitudes of Foreign Companies Regarding a US Listing, A. Stanford Journal of Law, Business \& Finance, v. 3, n. 1, p. 51-83, 1997.

FELIPE, P. S.; DIRANZO, F. C. Volatility transmission models: a survey. Revista de Economía Financiera, n. 10, p. 32-81, 2006.

FORBES, K. J.; RIGOBON, R. No contagion, only interdependence: measuring stock markets co-movements. The Journal of Finance, v. 57, n. 5, p. 2223-2261, 2002

GRAHAM, M.; KIVIAHO, J.; NIKKINEN, J. Integration of 22 emerging stock markets: A three-dimensional analysis. Global Finance Journal, v. 23, n. 1, p. 34-47, 2012. 
HALES, A. D.; MOLLICK, A. V. The impact of ADR activity on stock market liquidity: Evidence from Latin America. The Quarterly Review of Economics and Finance, v. 54, n. 3, p. 417-427, 2014.

HUANG, W.; CHEN, Z. Modeling regional linkage of financial markets. Journal of Economic Behavior \& Organization, v. 99, p. 18-31, 2014.

HWANG, J. Spillover Effects of the 2008 Financial Crisis in Latin America Stock Markets. International Advances in Economic Research, v. 20, n 3, p. 311-324, 2014

JINJARAK, Y. Equity prices and financial globalization. International Review of Financial Analysis, v. 33, p. 49-57, 2014.

KALEMLI-OZCAN, S.; PAPAIOANNOU, E.; PEYDRÓ, J. Financial regulation, financial globalization, and the synchronization of economic activity. The Journal of Finance, v. 68, n. 3, p. 1179-1228, 2013.

KENOURGIOS, D.; DIMITRIOU, D. Contagion of the Global Financial Crisis and the real economy: A regional analysis. Economic Modelling, v. 44, p. 283-293, 2015.

KIYMAZ, H.; ALON, I.; VEIT, E. T. Examining the returns of American depository receipts: Evidence from emerging and developed markets. Thunderbird International Business Review, v. 51, n. 6, p. 567-581, 2009.

KOUTMOS, G.;BOOTH, G. G. Asymmetric volatility transmission in international stock markets. Journal of International Money and Finance, v.14, n 6, p. 747-762, 1995

LEVINE, R.; SCHMUKLER, S. L. Internationalization and stock market liquidity. Review of Finance, v. 10, n. 1, p. 153-187, 2006.

LI, F. Identifying asymmetric comovements of international stock market returns. Journal of Financial Econometrics, v. 12, n. 3, p. 507-543, 2014

LÜTKEPOHL, H. Comparison of criteria for estimating the order of a vector autoregressive process. Journal of Time Series Analysis, v. 6, n. 1, p.35-52, 1985

MARÇAL, E. F.; PEREIRA, P. L. V.; MARTIN, D. M. L.; NAKAMURA, W. T. Evaluation of contagion or interdependence in the financial crises of Asia and Latin America, considering the macroeconomic fundamentals. Applied Economics, v. 43, n. 19, p. 2365-2379, 2011.

MARKOWITZ, H. Portfolio selection. The journal of finance, v. 7, n. 1, p. 77-91, 1952.

MARTINEZ, C.; RAMIREZ, M. International propagation of shocks: an evaluation of contagion effects for some Latin American countries. Macroeconomics and Finance in Emerging Market Economies, v. 4, n. 2, p. 213-233, 2011.

MATOS, P.; SIQUEIRA, A.; TROMPIERI, N. Análise de integração e contágio financeiro na América do Sul. Revista Brasileira de Economia, v. 68, n. 2, p. 277-299, 2014.

MERIC, G.; LEAL, R. P. C.; RATNER, M.; MERIC, I. Co-movements of US and Latin American equity markets before and after the 1987 crash. International Review of Financial Analysis, v. 10, n. 3, p. 219$235,2001$.

MITTOO, U. R. Managerial perceptions of the net benefits of foreign listing: Canadian evidence. Journal of International Financial Management \& Accounting, v. 4, n. 1, p. 40-62, 1992.

MODY, A. What is an emerging market? IMF Working Paper, International Monetary Fund, n. 04/177, p. 1-23, 2004.

MORCK, R.; YEUNG, B.; YU, W. The information content of stock markets: why do emerging markets have synchronous stock price movements? Journal of financial economics, v. 58, n. 1, p. 215-260, 2000.

NING, C.; XU, D.; WIRJANTO, T. S. Is volatility clustering of asset returns asymmetric? Journal of Banking \& Finance, v. 52, p. 62-76, 2015.

OBADAN, M. I. Globalization of finance and the challenge of national financial sector development. Journal of Asian Economics, v. 17, p. 316-332, 2006.

PAGÁN, J. A.; SOYDEMIR, G. A. Response asymmetries in the Latin American equity markets. International Review of Financial Analysis, v. 10, n 2, p. 175-185, 2001.

PATEL, J. B. Stock Returns of Developed and Emerging Markets of Europe. Journal of International Business Research, v. 7, n. 1, p. 35-45, 2008.

PIMENTA JR., T. Os mercados de capitais do BRIC já se comportam como desenvolvidos? Uma análise dos efeitos de volatilidade no contexto da crise financeira internacional de 2008. 2012. 268 p. Tese (Livre-docência) - Faculdade de Economia, Administração e Contabilidade de Ribeirão Preto, Universidade de São Paulo, Ribeirão Preto, 2012.

PRAETZ, P.D. The distribution of share price changes. Journal of Business, v. 45, p. 49-55, 1972

RAMOS, S. B.; VERMUNT, J. K.; DIAS, J. G. When markets fall down: are emerging markets all the same? International Journal of Finance \& Economics, v. 16, n. 4, p. 324-338, 2011. 
BBR

15,4

409

REJEB, A. B.; ARFAOUI, M. Financial market interdependencies: A quantile regression analysis of volatility spillover. Research in International Business and Finance, v. 36, p.140-157, 2016.

ROMERO-MEZA, R.; BONILLA, C.; BENEDETTI, H.; SERLETIS, A. Nonlinearities and financial contagion in Latin American stock markets. Economic Modelling, v. 51, p. 653-656, 2015.

SANTOS, C. M. Comportamento dos mercados do BRICS a partir da Crise do Subprime: uma análise dos fenômenos de interdependência e contágio e seus reflexos nas características dos grupos dos países analisados. 2015. 189 p. Tese (Doutorado) - Faculdade de Economia, Administração e Contabilidade de Ribeirão Preto, Universidade de São Paulo, Ribeirão Preto, 2015.

SYRIOPOULOS, T.; MAKRAM, B.; BOUBAKER A. Stock market volatility spillovers and portfolio hedging: BRICS and the financial crisis. International Review of Financial Analysis, v. 39, p. 7-18, 2015.

VALENZUELA, G.;RODRIGUEZ, A. Interdependencia de mercados y transmisión de volatilidad en latinoamérica. Revista Innovar, v. 25, n.55, p.157-170, 2015

VÁZQUEZ, O. H. Z.; JIMÉNEZ, J. G. M. The implicit impact of cross-listing on stock prices: A market microstructure perspective - The case of Latin American markets. Contaduría y Administración, v. 61, p. 283-297, 2016.

WANG, A. T.; LI, M. L.; CHEN, T. Price transmission, foreign exchange rate risks and global diversification of ADRs. Applied Economics, v. 42, n. 14, p. 1811-1823, 2010.

WANG, A. T.; YAO, C. Risks of Latin America sovereign debts before and after the financial crisis. Applied Economics, v. 46, n. 14, p. 1665-1676, 2014. 